\title{
Recent Advances in the Chemistry of Oripavine and Its Derivatives
}

\author{
Sandor Hosztafi \\ Institute of Pharmaceutical Chemistry, Semmelweis University, Budapest, Hungary \\ Email: hosztafi.sandor@pharma.semmelweis-univ.hu
}

Received 2 May 2014; revised 16 June 2014; accepted 12 July 2014

Copyright (C) 2014 by author and Scientific Research Publishing Inc. This work is licensed under the Creative Commons Attribution International License (CC BY). http://creativecommons.org/licenses/by/4.0/

(c) (i) Open Access

\begin{abstract}
Oripavine is the major alkaloid of Papaver orientale. It is an important intermediate in the biosynthesis of morphine alkaloids. Recently, new Papaver somniferum strains have been developed which accumulate thebaine and oripavine, but not morphine and codeine. Therefore, the chemistry of oripavine has been studied intensively to synthesize opioid pharmaceuticals such as oxymorphone, naloxone and buprenorphine.
\end{abstract}

\section{Keywords}

Papaver orientale, Papaver somniferum, Oripavine, Thebaine, Top1 Poppy

\section{Introduction}

Thebaine an alkaloid present in $0.2 \%-0.8 \%$ in opium and a major constituent ( $90 \%$ of total alkaloid content) in Papaver bracteatum (which is morphine free), possesses little utility medically for two reasons: (a) its lack of the depressant and analgesic properties common to other morphine alkaloids and (b) its expression of extreme toxicity and CNS stimulation. Oripavine is also a minor alkaloid of the opium poppy, but it is the main alkaloid of the oriental poppy Papaver orientale, which is a perennial flowering plant. The development of the top1 poppy was an important finding for the opium industry in Australia, because this poppy strain produces thebaine and oripavine, but not morphine or codeine. Both thebaine and oripavine possess a conjugated diene system at ring $C$ and chemical modifications resulted in numerous opioid pharmaceuticals, for instance the 14-hydroxy opioid antagonists and the 6,14-endoetheno and 6,14-endoethano derivatives. This paper will survey the recent developments of the chemistry and biochemistry of oripavine.

\section{Occurrence and Isolation}

\subsection{Isolation of Oripavine}

Oripavine (1) was isolated as a major alkaloid of Papaver orientale in 1935 by a Russian research team [1]. It 
was shown to contain N-methyl and O-methyl groups and a phenolic hydroxyl group. O-methylation with diazomethane yielded thebaine (2), corroborating its structure namely it is 3-O-demethylthebaine. Oripavine always occurs together with thebaine in Papaver orientale. For instance, Shafiee et al. [2] [3] found 20\% oripavine and 9\% thebaine in the dry latex of Papaver orientale. There are several papers [4]-[7] in which the detection and identification of oripavine was reported. The structure of oripavine was also elucidated by spectral (NMR, MS and UV) studies [3] [8] [9].

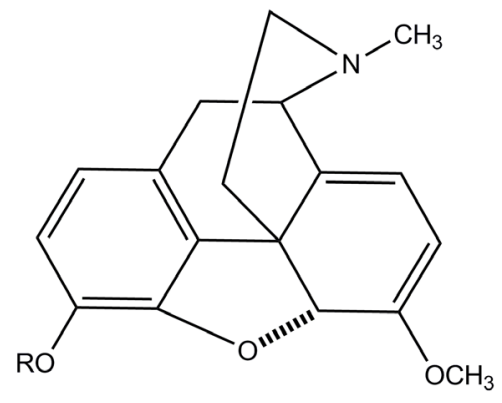

$$
\begin{aligned}
& \mathrm{R}=\mathrm{H} \text { Oripavine } 1 \\
& \mathrm{R}=\mathrm{CH}_{3} \text { Thebaine 2 }
\end{aligned}
$$

Numerous papers were published about the isolation of oripavine from Papaver bracteatum. In a critical review H. Bohm [10] considered these accounts unreliable. Slavik and Slavikova in a detailed study did not detect oripavine in Papaver bracteatum [11]. Nevertheless Rapoport et al. also reported similar results [12]. The biosynthesis of morphinan alkaloids was examined in Papaver bracteatum and the O-demethylation of radioactive labelled thebaine to oripavine was not observed. In 1992 Sariyar et al. [13] detected oripavine (trace amount) in the capsules of Turkish Papaver bracteatum. It is notable that oripavine was found between the alkaloids of hybrids of Papaver bracteatum and Papaver orientale [14].

Oripavine, thebaine, narcotine and rhoeadine were isolated as the main alkaloids from Papaver cylindricum Cullen [8]. It was the first report on the isolation of morphinan alkaloids in the Milthantha species. Slavik and Slavikova isolated oripavine as a major alkaloid from the plant Papaver pinnatifidum Moris of the section Rhoeadium Spach [9].

Oripavine was isolated from the dried capsules of a variety of Papaver somniferum cultivated on Tasmania in 1983 by E. Brochmann-Hanssen [15]. The Indian land races of opium poppy was examined for the capsule husk contents of 5 opium alkaloids morphine, codeine, thebaine, papaverine and narcotine and 3 biosynthetic intermediates reticuline, codeinone and oripavine [16]. The alkaloid profiles and correlations between alkaloids showed that in the Indian genetic resources of $P$. somniferum (a) morphine is synthesized from codeine rather than oripavine and (b) accumulation of morphine and codeine was limited upstream of codeinone and morphinone. Oripavine, in general was present in very low amounts.

\subsection{Biosynthesis of Oripavine}

Radioactive labelled thebaine was converted to oripavine by C-3 O-demethylation in the plant of Papaver orientale [17]. Feeding experiments in Papaver orientale with radioactively labelled reticuline and thebaine have proved that oripavine is derived from reticuline via thebaine [18]. Reticuline undergoes racemization in this plant as has been earlier shown for $P$. somniferum and $P$. bracteatum.

\subsection{Biosynthesis of Morphinan Alkaloids}

(R)-Reticuline (3) is a very important intermediate in the biosynthesis of morphinan alkaloids. It is converted into salutaridine (4) which is the first alkaloid containing morphinan skeleton. The reaction is an oxidative phenol coupling that establishes the characteristic stereochemistry of (-) morphinans. This coupling is catalyzed by salutaridine synthase a microsomal NADPH dependent cytochrome P-450 enzyme [19]-[21]. 

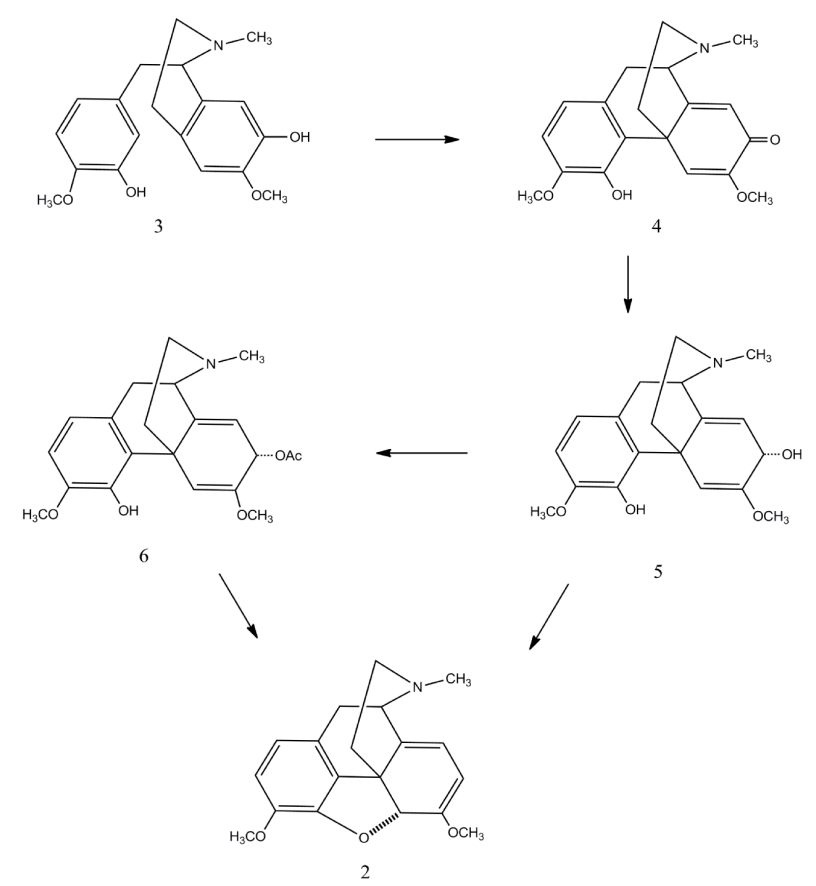

Salutaridine is then reduced by the NADPH dependent salutaridine reductase to form salutaridinol (5), followed by the closure of the oxygen bridge between C4 and C5 to form the distinctive pentacyclic morphinan skeleton. Salutaridinol possesses the correct 7-S configuration for the allylic syn-displacement of the activated hydroxyl group by the C-4 phenolic hydroxyl group which follows the established stereochemistry for SN2' substitution at the cyclohexene ring. First the hydroxyl group is activated by an acetylation catalyzed by salutaridinol 7-O-acetyltransferase. 7-O-Acetyl salutaridinol (6) at slightly alkaline $\mathrm{pH}$ values spontaneously rearranges to thebaine by closing the oxide bridge between C-4 and C-5 [19]-[21].
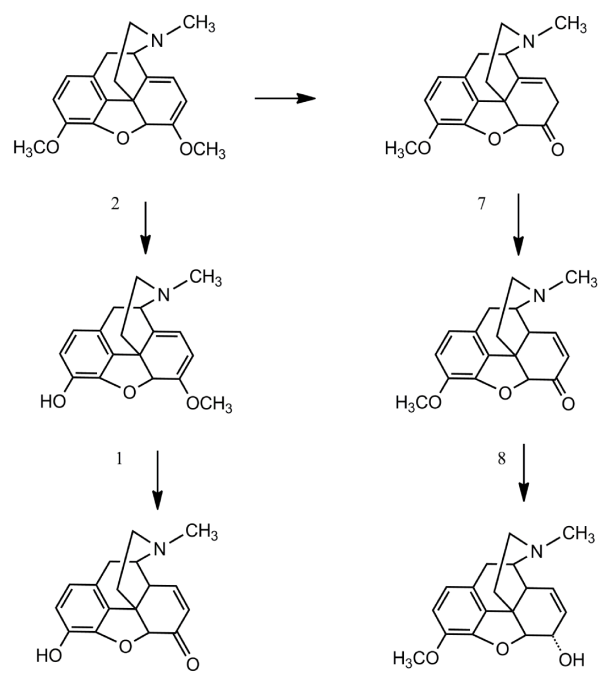

11
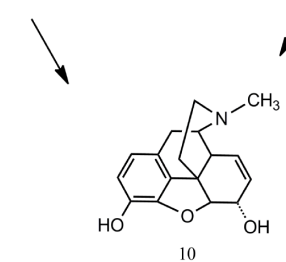
Precursor feeding studies in $P$. somniferum using labelled thebaine have shown that the enol ether cleavage involves the loss of the C-6 O-methyl group with retention of the 6-oxygen, possibly through a mechanism involving an oxygenase [22]. In species such as $P$. bracteatum and $P$. orientale, which lack enzymes for this Odemethylation, biosynthesis stops at thebaine and branches to oripavine by demethylation of the phenolic ether at $\mathrm{C}-3$.

O-Demethylation at position C-6 is catalyzed by thebaine 6-O-demethylase (T6ODM), whereas O-demethylation at position C-3 is catalyzed by codeine O-demethylase (CODM). These enzymes [23] were identified as $\alpha$-ketoglutarate/non-heme iron (II) dependent dioxygenases, in contrast to the functionally analogous cytochrome P450s found in mammals.

Thebaine can undergo O-demethylation at position C-6 or position C-3 to yield neopinone (7) or oripavine, respectively. Neopinone spontaneously rearranges to the more stable codeinone (8) in aqueous solution over a wide $\mathrm{pH}$ range, a process that is accelerated under physiological conditions by the reduction of codeinone to codeine (9) by codeinone reductase (COR ). Codeine is demethylated by CODM to produce morphine (10) [19][21]. Demethylation of oripavine by T6ODM yields morphinone (11), which is reduced to morphine by COR. The opium poppy variety top1 is blocked at T6ODM, and accumulates thebaine and oripavine rather than morphine and codeine.

It has clearly been shown by Brochmann-Hanssen [24] that in opium poppy a second pathway exists to morphine via oripavine. This implies a cleavage of the phenolic O-methyl group at C-3 of thebaine. 2-3H-Oripavine was administered to mature Papaver somniferum plants from two different chemical strains, one of which was known to contain oripavine. Morphinone (11) was synthesized and used as carrier. Incorporation of oripavine into morphine was $28.1 \%$ and $21.4 \%$, respectively. Morphinone decomposed during isolation, but the small amount isolated from one batch showed an incorporation of $4.5 \%$. Thebaine and codeine were not radioactive. Therefore, the 3-O-demethylation of thebaine is not reversible. These results strongly suggest that the formation of oripavine represents a step on a second pathway from thebaine to morphine.

\subsection{Biosynthesis of Morphinans in Mammalian Cells}

Since the beginning of the 80s, endogenous morphine with an identical structure to that of morphine isolated from poppy, has been characterized in numerous mammalian cells and tissues. Morphine has also been found in cancer cell lines originating from human and animal cells. Reports over the past twenty years indicated the occurrence of morphine in humans and animals but these results did not prove whether this morphine was produced in animals de novo. Conclusive evidence of de novo morphine synthesis in mammals was provided by the laboratory of Prof. M. H. Zenk.

Zenk et al. [25] have unequivocally demonstrated that human neuroblastoma cells are able to synthesize morphine. The metabolic route starting from L-tyrosine involving at least 19 chemical steps shares remarkable similarities with the morphine biosynthesis in opium poppy. Their results confirmed that codeine and oripavine are intermediates of morphine biosynthesis in human cells. This finding, in turn, implies that thebaine can serve as a substrate for two different competing cytochrome P450-dependent methyl ether cleaving enzymes acting either first at position C-3 or C-6, exactly as in the poppy plant.

The biosynthesis of endogenous morphine was observed when tetrahydropapaveroline was injected intraperitoneally into mice and the urine was analyzed [26]. The biosynthesis of morphine proceeds via (R)-reticuline to salutaridine, salutaridinol and thebaine, all of which were found in mice urine after injection of relevant precursors. Thebaine injection into mouse yielded codeine, oripavine, and morphine. These findings indicate the presence of the bifurcate pathway found previously in plant morphine biosynthesis.

\subsection{Development of the Top1 Poppy}

In Australia since 1994 the Tasmanian Alkaloids, the biggest grower of opium poppies, pursued a systematic research in order to develop a high thebaine poppy variety, and to simplify the processing of the alkaloids, thereby increasing production efficiency. These efforts led to the development of top1 poppy utilizing chemical mutagenesis [27] [28].

The seeds of a commercial poppy cultivar (Papaver somniferum) were treated with ethyl methanesulfonate as a mutagen. After the seeds have been exposed to the mutagen, the seeds were grown to maturity in controlled conditions and self-pollinated. The seeds from the mature plant are taken and at least one seed was planted to 
grow an M2 generation. The M2 generation plant designated Papaver somniferum Norman was examined for alkaloid production. The threshed poppy straw or opium having thebaine and oripavine constitutes about $50 \%$ by weight or greater of the alkaloid combination consisting of morphine, codeine, thebaine and oripavine. The mutant top1 poppy was found to accumulate thebaine and oripavine but not morphine or codeine. Feeding of radioactive intermediates confirmed that there is a metabolic block in top1 which was suggested to result from a defect in the enzyme catalyzing 6-O-demethylation of thebaine and oripavine. This cultivar produces approximately the same quantities of alkaloids per hectare, but with thebaine and oripavine (not morphine) as the major constituents. The straw of the major alkaloid content of the Papaver somniferum N. (PSN) cultivar was determined and the reported figure is percent by weight of the dry straw: thebaine $(2.0 \%)$, oripavine $(0.8 \%)$, codeine (0.01\%) and morphine (0.05\%) compared with the traditional Papaver somniferum L. (PSL) cultivar with morphine $(2.4 \%)$, codeine $(0.1 \%)$, oripavine $(0.03 \%)$ and thebaine $(0.1 \%)$ by dry weight. Morphine is present as a by-product from PSL infestation as a weed in the PSN crop and there is significant season-to-season variation in these minor alkaloids (morphine and codeine). Since initial plantings in 1996 PSN now accounts for 60\% of the crop under cultivation. Isolation of morphine from PSN is accomplished by means of harvesting and extraction of the poppy straw (PSN does not 'bleed' opium sap).

\section{Chemistry of Oripavine}

\subsection{Analytical Determination and Separation of Oripavine}

Rapid and accurate methods are required to determine the $P$. somniferum alkaloids for samples such as raw plant materials (to establish or screen alkaloid content in different crops), industrial process streams (to optimise the extraction yields and reduce waste) and pharmaceutical formulations (for quality control and regulatory requirements). Chromatographic methods have been extensively used for the separation and quantitation of the alkaloids in opium and in poppy straw. Thin-layer chromatography (TLC) is also utilized for the identification of alkaloids and screening of opium samples prior to further examination by other chromatographic methods.

High-performance liquid chromatography (HPLC) with UV-Vis detection as the determinative step is the method of choice for the quantitative determination of opium alkaloids [14] [29]-[31]. Barnett et al. [32] established a dual chemiluminescence reagent for the determination of the opiate alkaloids morphine, codeine, oripavine, and thebaine in Papaver somniferum extracts. Detection was achieved using a mixture of acidic potassium permanganate and tris(2,2'-bipyridyl)ruthenium(II), where the former acted as both the oxidant for the latter and as a chemiluminescence reagent in its own right. The analytes were separated on a C8 column using ion-pairing HPLC. Detection limits for the alkaloids were $10^{-6}, 5 \times 10^{-7}, 3 \times 10^{-6}$, and $2 \times 10^{-6} \mathrm{~mol} \cdot \mathrm{L}^{-1}$ for morphine, codeine, oripavine, and thebaine, respectively. Further developments on this method were reported from this research group [33].

Recently capillary electrophoresis procedures for the determination of opium alkaloids in process monitoring, pharmaceutical and forensic science applications have been reported [34] [35]. Most of these have incorporated UV-absorbance detection, which has limited sensitivity due to the small internal diameter of the separation capillary. Chemiluminescence detection was also utilized as a low-cost option to increase the sensitivity and selectivity. Barnett et al. [36] elaborated a simple and robust capillary electrophoresis chemiluminescence detection system for the determination of morphine, oripavine and pseudomorphine, based upon the reaction of these analytes with acidic potassium permanganate in the presence of sodium polyphosphate.

Odell et al. [37] recommended a unique marker compound for the identification of illicit heroin of Tasmanian origin. Tasmanian poppies contain a unique alkaloid, oripavine, which is the source of 'marker' impurities in illicit heroin produced from Tasmanian poppy straw. Treatment of oripavine with acetic anhydride under the heroin processing conditions, followed by simple evaporative workup afforded a crude residue, which upon extensive chromatographic purification yielded several compouds. Oripavine displays the same type rearrangement products like thebaine. Nevertheless, there is no evidence to suggest that heroin has ever been produced from Tasmanian poppies.

Oripavine was detected as its 3-O-trimethylsilyl derivative in the urine specimen of opium users. The urine sample was subjected to enzymatic hydrolysis and derivatization for its GC-MS analysis. El Haj et al. [38] proposed oripavine as a useful putative marker of opium use. They explained the presence of oripavine in the urine of opium users by the O-demethylation of thebaine. 


\subsection{Synthesis of Thebaine}

The opium alkaloids thebaine and oripavine are considered as the enol methyl ethers of codeinone and morphinone respectively. The preparation of the enol ethers of $\alpha, \beta$-unsaturated ketones is well established in synthetic organic chemistry. Seki [39] elaborated an one-step formation of enol ethers from codeinone (8) with various alcohols in the presence of p-toluenesulfonic acid catalyst. Thebaine was obtained in low (27\%) yield.
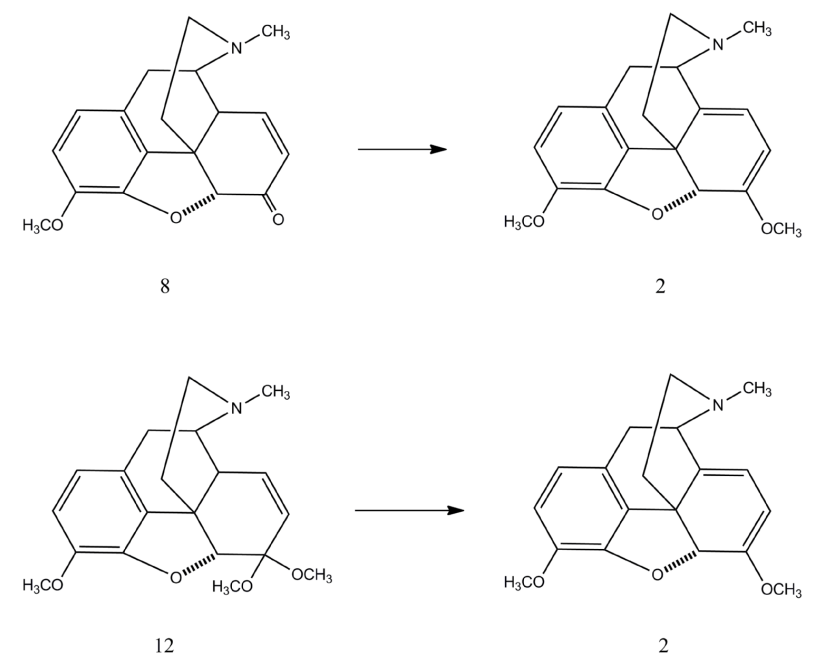

Coop and Rice [40] published another modification of this reaction: Codeinone (8) was methylated with methyl sulfate in the presence of potassium tert. butoxide base and 18-crown-6 catalyst. Thebaine was prepared in $54 \%$ yield.

Rapoport et al. [41] [42] reported the synthesis of thebaine from codeinone dimethyl ketal (12). The elimination of methanol from codeinone dimethyl ketal was performed with phosphorous oxychloride in pyridine resulting an $80 \%$ yield of thebaine. Codeinone dimethyl ketal was obtained fom dihydrocodeinone in three steps.

Utilizing suitable protecting groups C-3 ethers or esters of oripavine can be prepared. Bartels-Keith [43] accomplished the synthesis of oripavine and N-cyclopropylmethyl-nororipavine using Rapoport method.

Singer and Scammells [44] achieved the manganese dioxide oxidation of codeine methyl ether (13), to thebaine (2) via the use of the ionic liquid 1-butyl-3-methylimidazolium tetrafluoroborate, bmim BF4. The ionic liquid has been used to remove or extract excess manganese dioxide and concomitant impurities from the reaction mixture to afford thebaine in $36 \%$ to $95 \%$ yield.
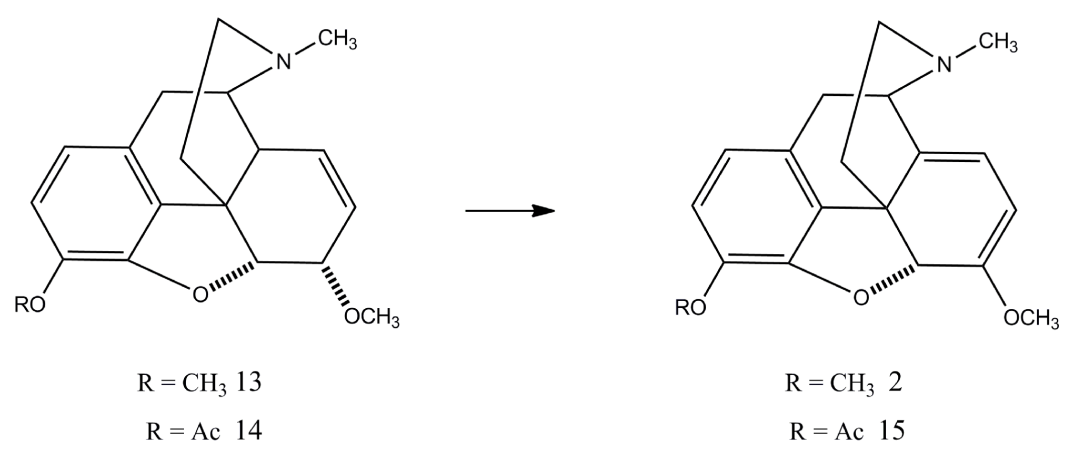

\subsection{Synthesis of Oripavine}

Barber and Rapoport [45] oxidized 3-O-acetyl-6-O-methylmorphine (14) with activated manganese (IV) oxide to obtain 3-O-acetyloripavine (15). The latter compound was hydrolysed to oripavine. The yields were 88 and $93 \%$ respectively and the reactions were performed on one mmole scale. (Oxidation of codeine methyl ether gave thebaine in $80 \%$ yield.) Klein et al. [46] utilized these reactions starting from 3-O-tertbutyldimethyl- 
silyl-6-O-methylmorphine yielding the C3-protected oripavine. The Diels-Alder reactions of 3-O-tertbutyldimethylsilyloripavine were studied with dienophiles such as acrolein and methyl vinyl ketone to furnish the corresponding adducts. This research team also reported the synthesis of N-Cyclopropylmethyl-3-O-tertbutyldimethylsilylnororipavine and its Diels-Alder reactions.

In principle, oripavine can be prepared from thebaine by selective C-3 O-demethylation. Unfortunately the C-6 enol methyl ether is very reactive and the cleavage of this ether leads to rearrangement reactions and decomposition. Coop et al. [47] [48] reported the first selective C-3 O-demethylation of thebaine with L-selectride and oripavine was isolated in 35\% yield. Oripavine was purified expediently by means of crystallization of the oxalate salt from methanol. The authors reported two reactions of oripavine. The reacion of oripavine-sulfate salt with m-chloroperbenzoic acid resulted in 14-hydroxymorphinone (16) in 62\% yield. The Diels-Alder reaction of oripavine with methyl vinyl ketone gave orvinone (18) in 82\% yield. Subsequent Grignard reaction of orvinone with methylmagnesium iodide afforded 19-methyl-orvinol.

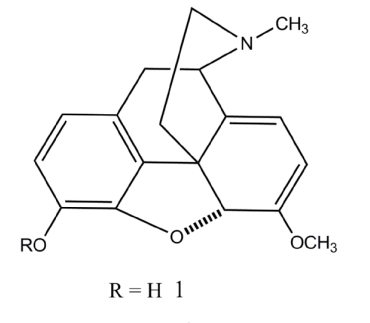

$\mathrm{R}=\mathrm{CH}_{3} 2$

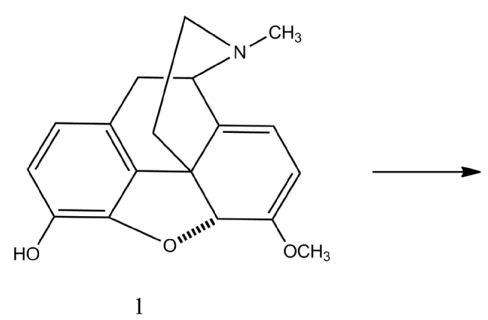

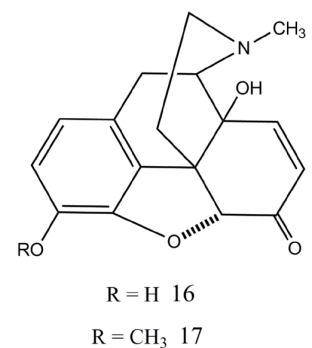

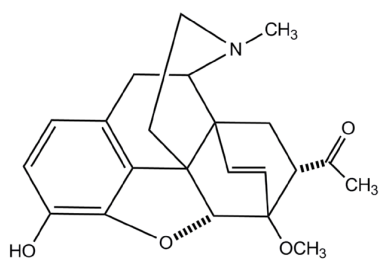

18

\section{Oripavine as a Starting Material for the Syntheses of Opioid Agonists and Antagonists}

Introduction of the C-14 hydroxyl group into a 4,5-epoxymorphinan nucleus may be accomplished from thebaine by hydrogen peroxide or peracid treatment resulting in 14-hydroxycodeinone (17). Catalytic reduction of the double bond yields oxycodone (14-hydroxydihydrocodeinone, 19) which can be converted to oxymorphone (20) by means of O-demethylation. Both compounds are more potent analgesics than morphine. However, oxymorphone is an important starting material for the synthesis of pure opioid antagonists such as naloxone (21) and naltrexone (22). First oxymorphone is subjected to N-demethylation reaction yielding noroxymorphone and $\mathrm{N}$-alkylation of this secondary amine will furnish naloxone and naltrexone. Therefore noroxymorphone is also a key intermediate in the synthesis of 14-hydroxy-substituted opioid antagonists.

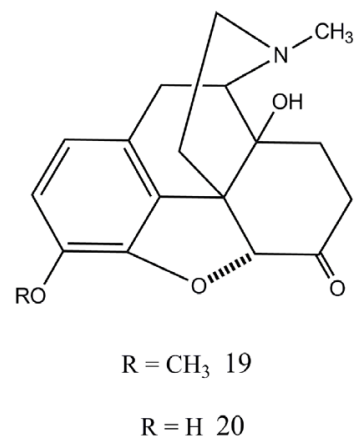

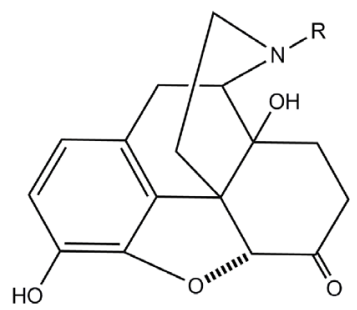

$\mathrm{R}=$ allyl 21

$\mathrm{R}=\mathrm{CH}_{2} \mathrm{C}_{3} \mathrm{H}_{5} 22$ 
Diels-Alder reaction of thebaine with dienophiles resulted in 6,14-endoethenotetrahydro-oripavines which possess outstanding pharmacological properties. Etorphine (23) is ca. 8000 times more potent analgesic than morphine. It is used to immobilize large wild game animals due to its margin of safety. Buprenorphine (24) is also a potent analgesic (partial opioid agonist) and it is used to treat heroin addiction, whereas diprenorphine (25) is a strong opioid antagonist. It is reasonable that the above-mentioned pharmaceuticals can be prepared from oripavine which is available from poppy straw. Oripavine may be useful as a starting material to avoid the difficult C-3 methyl ether cleavage in the preparation of 6,14-endoeheno-tetrahydrooripavines.
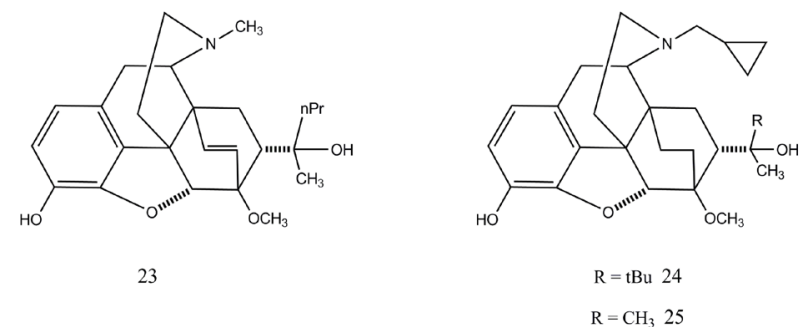

\subsection{N-Demethylation of Thebaine and Oripavine}

N-Demethylation of thebaine was studied with cyanogen bromide or various chloroformates but these reactions led to the scission of C-9-N bond. Diethyl azodicarboxylate has been reported to be an effective reagent for the $\mathrm{N}$-demethylation of thebaine to northebaine.

Sipos and coworkers [49] reported the synthesis of nororipavine (28) in which thebaine was treated with diethyl azodicarboxylate to afford the corresponding N-nor-N-\{[1,2-bis(ethoxycarbony)-hydrazinyl]methyl $\}$ derivative. Subsequent treatment of this intermediate with L-Selectride effected simultaneous O- and N-dealkylations, giving N-nororipavine (28) in an overall yield of $43 \%$.

Scammells et al. [50] employed a modified nonclassical Polonovski reaction for the N-demethylation of morphine alkaloids and this method was suitable for the preparation of northebaine (29) and nororipavine (28). This approach involved the conversion of the tertiary $\mathrm{N}$-methyl amine to the corresponding $\mathrm{N}$-oxide (by treatment with hydrogen peroxide or m-chloroperbenzoic acid) followed by treatment with iron sulfate. Morphine derivatives with various structures were successfully $\mathrm{N}$-demethylated using this procedure in moderate to high yield. In all cases, the major by-product formed during the iron sulfate step was the parent $\mathrm{N}$-methyl compound. It was found that isolation of the corresponding $\mathrm{N}$-oxide as its hydrochloride (26 and 27) salt prior to iron treatment afforded superior yields of the desired ' $\mathrm{N}$-nor' product. One of the limitations of the iron salt-mediated variant of the Polonovski reaction is the difficulty in separating the product from the iron salts. The use of EDTA as an iron-chelating agent in the reaction work-up proved to be effective in removing iron salts in a number of cases.
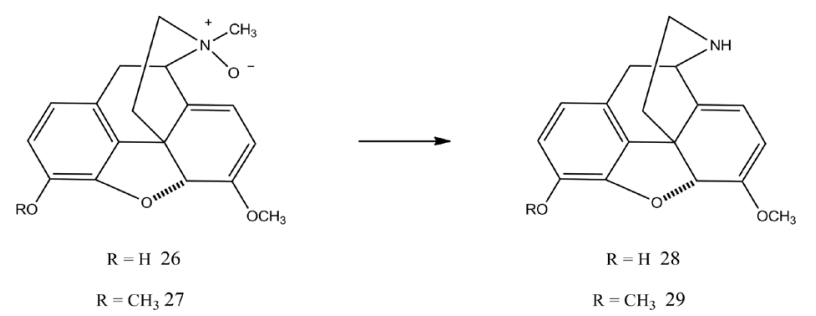

It was found the reaction of the N-oxide of morphine alkaloids (hydrochloride salt) with sulfonated tetraphenylporphyrin-iron (II) complex [51] took place readily yielding the corresponding N-nor derivatives in high yields. The catalyst was readily removed and recycled. Northebaine $(27 \rightarrow 29)$ was prepared in $69 \%$ yield.

Later on, Kok and Scammells [52] reported that under Polonovski-type conditions, ferrocene has been found to be a convenient and efficient catalyst for the N-demethylation of a number of morphine alkaloids, including key pharmaceutical intermediates such as oxycodone and oxymorphone. Thus, the tertiary N-methylamine is first converted into the corresponding $\mathrm{N}$-oxide hydrochloride which, following subsequent treatment with the ferrous reagent, has provided the N-nor compound in moderate to good yields. In most cases, the only by-prod- 
uct obtained is the parent tertiary amine. This method offers a number of advantages with the ferrocene catalyst being inexpensive and readily available, as well as being air and thermally stable. If desired, most of the catalyst could readily be recovered from the reaction via a simple extraction with hexane or column chromatography. The reaction is mild and, as demonstrated for substrates such as oripavine, morphine, and oxymorphone, does not require protection of functional groups such as hydroxyl.

Further development of the Polonovski-type N-demethylation has been reported by Kok and Scammells, and they found that the Polonovski reaction took place in the presence of iron powder catalyst [53]. The tertiary $\mathrm{N}$-methylamine was first oxidized to the corresponding $\mathrm{N}$-oxide, which was isolated as the hydrochloride salt. Subsequent treatment of the N-oxide hydrochloride with iron powder readily provided the N-demethylated amine. Iron powder, using iso-propanol as solvent, was effective in the N-demethylation of morphine, thebaine and oxycodone resulting in high yields after column chromatography. N-demethylation of oripavine was performed in low yield.

Kok and Scammells [54] achieved detailed investigations into the direct synthesis of N-nororipavine (28) from oripavine using iron powder under nonclassical Polonovski conditions. The stoichiometry, solvents and iron oxidation rates were found to have a dramatic effect on the rate of $\mathrm{N}$-demethylation as well as product yield. The authors described a high-yield procedure to the N-demethylated product simply by employing stainless steel rather than iron powder as redox catalyst.

In these methods the utilized reagents are cheap, but the drawback that the $\mathrm{N}$-nor derivative always contains the parent $\mathrm{N}$-methyl compound as a by-product and the separation can be performed by means of column chromatography.

\subsection{Syntheses of 14-Hydroxymorphinans from Oripavine}

Kok and Scammells [55] elaborated a new procedure for the syntheses of oxymorphone and noroxymorphone directly from oripavine and nororipavine respectively.

Oxidation of thebaine (2) hydrochloride was performed with m-chloroperbenzoic acid in $10 \%$ acetic acid at ambient temperature. 14-hydroxycodeinone (17) hydrochloride was obtained in a $98 \%$ yield. In the same way, 14-hydroxymorphinone (16) hydrochloride was prepared from oripavine (1) hydrochloride, again in an excellent yield (99\%). Both compounds had purities of 95\% and 94\% respectively, according to HPLC analysis. Similar results were obtained for the reduction of 14-hydroxymorphinone (16) hydrochloride, with the reduction in methanol over $5 \% \mathrm{Pd} / \mathrm{BaSO}_{4}$ resulting in oxymorphone (20) hydrochloride in a $98 \%$ yield and a purity of $94 \%$ by HPLC.

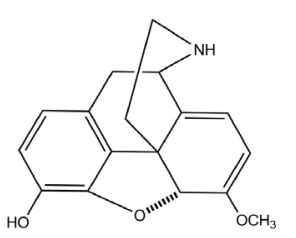

28

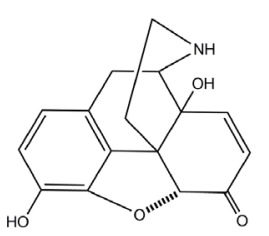

30

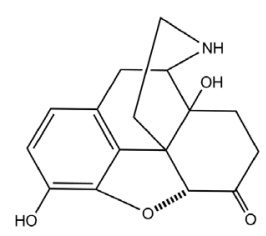

The improved oxidation-reduction protocol was also investigated for the direct synthesis of noroxymorphone (31) from nororipavine (28). Oxidation of nororipavine (28) hydrochloride using with m-chloroperbenzoic acid in 10\% acetic acid at ambient temperature afforded 14-hydroxy-normorphinone (30) hydrochloride in a 99\% yield (purity 96\% via HPLC). The latter was hydrogenated in methanol using 5\% Pd/BaSO4 catalyst and furnished noroxymorphone (31) hydrochloride in a $97 \%$ yield with a purity of 95\% via HPLC. Noroxymorphone was alkylated with cyclopropylmethyl bromide to furnish naltrexone (22) in 95\% yield. 

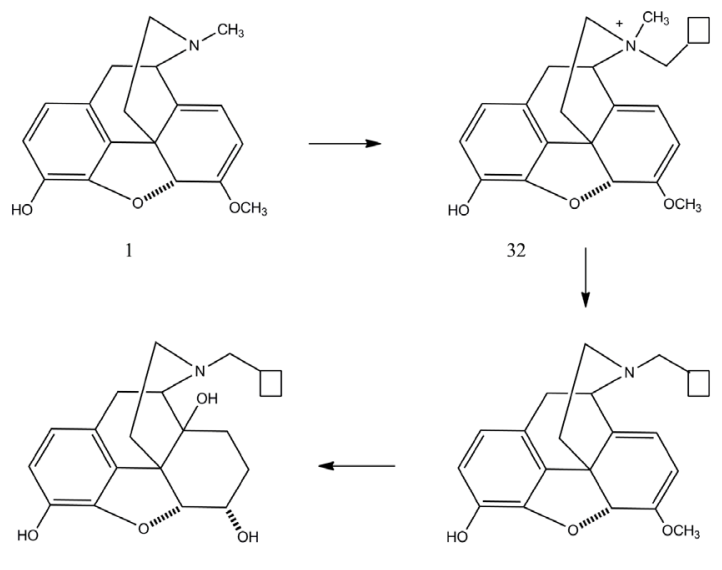

34

33

Hudlicky et al. [56] reported a quaternization/N-demethylation protocol for the synthesis of nalbuphine (34) from oripavine. Quaternization of oripavine with cyclobutylmethyl bromide resulted in a mixture of diastereomer quaternary ammonium salts (32) $(\mathrm{S}: \mathrm{R}=3: 1)$ in excellent yield. The $\mathrm{N}$-demethylation of the quaternary salts was achieved with sodium thiolate derived from 1-dodecanethiol in dimethyl sulfoxide at elevated temperature providing the desired N-cyclobutylmethylnororipavine (33) in consistent yields of 60\%. The latter compound was oxidized with peracetic acid yielding the 14-hydroxy-morphinone derivative, which was subjected to catalytic hydrogenation $\left(\mathrm{H}_{2} / \mathrm{Pd}-\mathrm{C}\right)$ to obtain nalbuphone. Nalbuphone was reduced $\left(\mathrm{H}_{2} / \mathrm{PtO}_{2}\right)$ to nalbuphine (34).

\subsection{Synthesis of Buprenorphine from Oripavine}

Hudlicky et al. [57] reported a novel synthetic sequence for the preparation of buprenorphine (24) utilizing oripavine as starting material. The major improvement over the previous synthesis is the elimination of cyanogen bromide as the reagent of $\mathrm{N}$-demethylation and avoidance of O-demethylation required in the route from thebaine.

Oripavine was converted to a mixture of diastereomeric quaternary salts (35) by heating with cyclopropylmethyl bromide in dimethyl formamide. The N-demethylation of the quaternary ammonium salts of oripavine was accomplished with tert-dodecanethiol as the nucleophilic reagent and sodium ethoxide as the base to give N-cyclopropylmethylnororipavine (36). The conversion of N-yclopropylmethylnororipavine to buprenorphine involves several steps which were elaborated previously. It was found that it is neccessary to protect the phenolic hydroxyl of N-cyclopropylmethylnororipavine by ethoxycarbonyl group. Subsequently the Diels-Alder reaction with methyl vinyl ketone (37), hydrogenation of the orvinone derivative and the Grignard reaction yielded the C-3 protected buprenorphine. Finally the ester protecting group was removed by hydrolysis with sodium hydroxide.

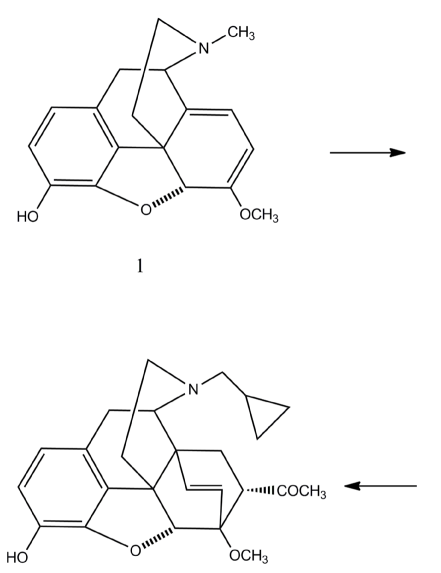

37

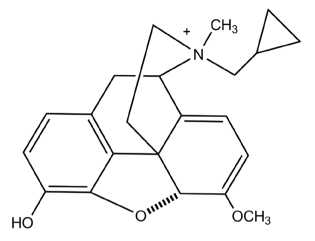

35

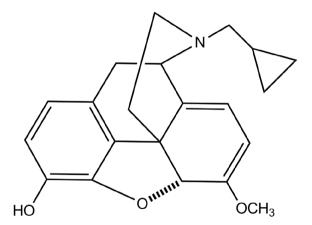

36 
Hudlicky et al. [58] elaborated another synthesis of buprenorphine from oripavine. Oripavine was converted to dihydroorvinone and its phenolic hydroxyl was protected with ethoxycarbonyl group (38). Grignard reaction with tert.-butylmagnesium chloride afforded the $\mathrm{N}$-methyl-tertiary alcohol derivative (39). The latter compound was treated with cyclopropanecarboxylic acid anhydride in the presence palladium and copper catalysts yielding the acyl amide of norbuprenorphine (40). This amide was reduced with lithium aluminium hydride or Red-Al resulting in the target compound buprenorphine (24).

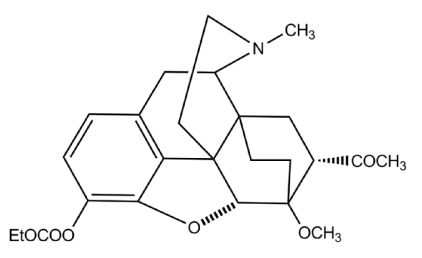

38
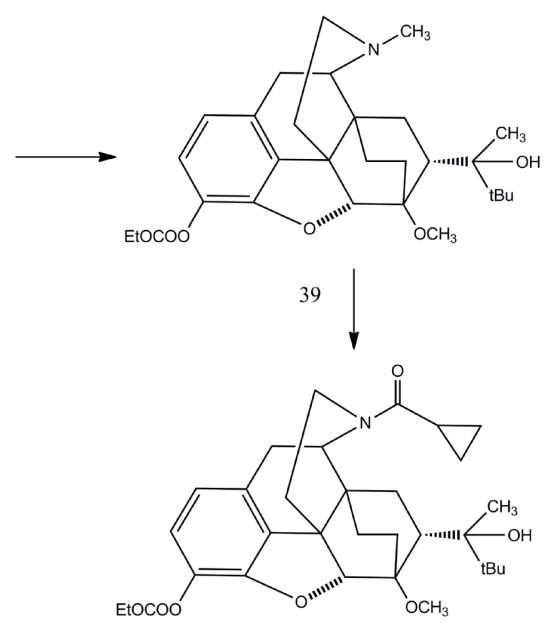

40

The research team of Mallincrodt Inc. took out a patent [59] for the preparation of norbuprenorphine, and ultimately buprenorphine, utilizing oripavine as the starting material. It was claimed that the use of oripavine does not require an O-demethylation step, since this reaction takes place in low to moderate yields. On the contrary, before N-demethylation of dihydroorvinone they used benzyl group to protect the phenolic hydroxyl. The protecting group was then removed by an additional step by means of catalytic hydrogenation.

It is mentionable that numerous patents [60]-[63] have been published covering the preparations of oxymorphone and buprenorphine from oripavine. Unfortunately, in these procedures the prepared new compounds have not been characterized, for example melting points, chromatographic properties and spectral data were not reported.

\section{References}

[1] Konowalowa, R., Yunosoff, S. and Orechoff, A. (1935) Uber Alkaloide der Papaver-Artem. I. Mitt.: Alkaloide von Papaver armeniacum und Papaver orientale. Berichte der Deutschen Chemischen Gesellschaft, 68, 2158-2163. http://dx.doi.org/10.1002/cber.19350681135

[2] Shafiee, A., Lalezari, I., Nasseri-Nouri, P. and Asgharian, R. (1975) Alkaloids of Papaver orientale and Papaver pseudoorientale. Journal of Pharmaceutical Sciences, 64, 1570-1572. http://dx.doi.org/10.1002/jps.2600640937

[3] Shafiee, A., Lalezari, I., Assadi, F. and Khalafi F. (1977) Alkaloids of Papaver orientale L. Journal of Pharmaceutical Sciences, 66, 1050-1052. http://dx.doi.org/10.1002/jps.2600660742

[4] Delenk-Heydenreich, K. and Pfeifer, S. (1969) Uber Alkaloide der Gattung Papaver. Part 32. Papaver orientale. Pharmazie, 24, 635-645.

[5] Vincent, P.G., Bare, C.E. and Gentner, W.A. (1976) Rapid Semi-Quantitative Spot Test for Determination of Thebaine and Differentation of Papaver bracteatum from P. orientale and P. pseudo-orientale. Lloydia, 39, 76-78.

[6] Phillipson, J.D., Scutt, A., Baytop, A., Ozhatay, N. and Sariyar, G. (1981) Alkaloids from Turkish samples of Papaver orientale and P. pseudo-orientale. Planta Medica, 43, 261-271. http://dx.doi.org/10.1055/s-2007-971507

[7] Slavik, J. and Slavikova, L. (1991) Polar Alkaloids from Papaver orientale L. Collection of Czechoslovak Chemical Communications, 56, 1534-1538. http://dx.doi.org/10.1135/cccc19911534

[8] Sariyar, G. (1982) Alkaloids from Papaver cylindricum. Planta Medica, 46, 175-178.

http://dx.doi.org/10.1055/s-2007-971208 
[9] Slavik, J. and Slavikova, L. (1994) Alkaloids from Papaver pinnatifidum Moris. Collection of Czechoslovak Chemical Communications, 59, 1879-1783. http://dx.doi.org/10.1135/cccc19941879

[10] Bohm, H. (1981) Papaver bracteatum Lindl.--Results and Problems of the Research on a Potential Medicinal Plant. Pharmazie, 36, 660-667.

[11] Slavik, J. and Slavikova, L. (1985) Alkaloids from Papaver bracteatum Lindl. Collection of Czechoslovak Chemical Communications, 50, 1216-1226. http://dx.doi.org/10.1135/cccc19851216

[12] Hodges, C.C., Horn, J.S. and Rapoport, H. (1977) Morphinan Alkaloids in Papaver bracteatum. Biosynthesis and Fate. Phytochemistry, 16, 1939-1942. http://dx.doi.org/10.1016/0031-9422(77)80100-3

[13] Sariyar, G., Gulyeze, H.B. and Gozler, B. (1992) Salutaridine N-Oxide from the Capsules of Papaver bracteatum. Planta Medica, 58, 368-369. http://dx.doi.org/10.1055/s-2006-961487

[14] Milo, J., Levy, A., Palevitch, D. and Ladizinsky, G. (1988) High Performance Liquid Chromatographic Analysis of the Alkaloid Spectrum in the Roots and Capsules of the Species and Hybrids of Papaver section Oxytona. Journal of Chromatography, 452, 563-570. http://dx.doi.org/10.1016/S0021-9673(01)81480-1

[15] Nielsen, B., Roe, J. and Brochmann-Hanssen, E. (1983) Oripavine: A New Opium Alkaloid. Planta Medica, 48, 205206. http://dx.doi.org/10.1055/s-2007-969921

[16] Prajapati, S., Bajpai, S., Singh, D., Luthra, R., Gupta, M.M. and Kumar, S. (2002) Alkaloid Profiles of the Indian Land Races of the Opium Poppy Papaver somniferum L. Genetic Resources and Crop Evolution, 49, 183-188. http://dx.doi.org/10.1023/A:1014763412736

[17] Stermitz, F.R. and Rapoport, H. (1961) The Biosynthesis of Opium Alkaloids. Alkaloid Interconversions in Papaver somniferum and Papaver orientale. Journal of the American Chemical Society, 83, 4045-4050. http://dx.doi.org/10.1021/ja01480a022

[18] Brochmann-Hanssen, E. and Cheng, C. Y. (1982) Biosynthesis of Hydrophenanthrene Alkaloids in Papaver orientale. Journal of Natural Products, 45, 434-436. http://dx.doi.org/10.1021/np50022a012

[19] Novak, B.H., Hudlicky, T., Reed, J.W., Mulzer, J. and Tauner, D. (2010) Morphine Synthesis and Biosynthesis-An update. Current Organic Chemistry, 4, 343-362. http://dx.doi.org/10.2174/1385272003376292

[20] Ziegler, J., Facchini, P.J., Geissler, R., Schmidt, J., Ammer, C., Kramell, R., Voigtlander, S., Gesell, A., Pienkny, S. and Brandt, W. (2009) Evolution of Morphine Biosynthesis in Opium Poppy. Phytochemistry, 70, 1696-1707. http://dx.doi.org/10.1016/j.phytochem.2009.07.006

[21] Hagel, J.M. and Facchini, P.J. (2013) Benzylisoquinoline Alkaloid Metabolism: A Century of Discovery and a Brave New World. Plant and Cell Physiology, 54, 647-672. http://dx.doi.org/10.1093/pcp/pct020

[22] Horn, J.S., Paul, A.G. and Rapoport, H. (1978) Biosynthetic Conversion of Thebaine to Codeinone. Mechanism of Ketone Formation from Enol Ether in Vivo. Journal of the American Chemical Society, 100, 1895-1898. http://dx.doi.org/10.1021/ja00474a041

[23] Hagel, J.M. and Facchini, P.J. (2010) Dioxygenases Catalyze the O-Demethylation Steps of Morphine Biosynthesis in Opium Poppy. Nature Chemical Biology, 6, 273-275. http://dx.doi.org/10.1021/ja00474a041

[24] Brochmann-Hanssen, E. (1984) A Second Pathway for the Terminal Steps in the Biosynthesis of Morphine. Planta Medica, 50, 343-345. http://dx.doi.org/10.1055/s-2007-969727

[25] Boettcher, C., Fellermeier, M., Boettcher, C., Drager, B. and Zenk, M.H. (2005) How Human Neuroblastoma Cells Make Morphine. Proceedings of the National Academy of Sciences of the United States of America, 102, 8495-8500. http://dx.doi.org/10.1073/pnas.0503244102

[26] Grobe, N., Lamshoft, M., Orth, R.G., Drager, B., Kutchan, T.M., Zenk, M.H. and Spiteller, M. (2010) Urinary Excretion of Morphine and Biosynthetic Precursors in Mice. Proceedings of the National Academy of Sciences of the United States of America, 107, 8147-8152. http://dx.doi.org/10.1073/pnas.1003423107

[27] Millgate, A.G., Pogson, B.J., Wilson, I.W., Kutchan, T.M., Zenk, M.H., Gerlach, W.L., Fist, A.J. and Larkin, P.J. (2004) Morphine-Pathway Block in Top1 Poppies. Nature, 431, 413-414. http://dx.doi.org/10.1038/431413a

[28] Fist, A.J., Byrne, C.J. and Gerlach, W.L. (2011) Production of Thebaine and Oripavine. US Patent 8067213 B2..

[29] Gomez-Serranillos, M.P., Palomino, O.M., Carretero, E. and Villar, A. (1998) Analytical Study and Analgesic Activity of Oripavine from Papaver somniferum L. Phytotherapy Research, 12, 346-349. http://dx.doi.org/10.1002/(SICI)1099-1573(199808)12:5<346::AID-PTR307>3.0.CO;2-A

[30] Singh, D.V., Prajapati, S., Bajpai, S., Verma, R.K., Gupta, M.M. and Kumar, S. (2000) Simultaneous Determination of Important Alkaloids in Papaver somniferum Using Reversed Phase High Performance Liquid Chromatography. Journal of Liquid Chromatography Related Technologies, 23, 1757-1764. http://dx.doi.org/10.1081/JLC-100100450

[31] Yoshimatsu, K., Kiuchi, F., Shimomura, K. and Makino, Y. (2005) A Rapid and Reliable Solid-Phase Extraction Me- 
thod for High-Performance Liquid Chromatographic Analysis of Opium Alkaloids from Papaver Plants. Chemical and Pharmaceutical Bulletin, 53, 1446-1450. http://dx.doi.org/10.1248/cpb.53.1446

[32] Lenehan, C.F., Barnett, N.W., Lewis, S.W. and Essery, K.M. (2004) Preliminary Evaluation of Dual Acidic Potassium Permanganate and Tris(2,2'-bipyridyl)-ruthenium(II) Chemiluminescence Detection for the HPLC Determination of Papaver somniferum Alkaloids. Australian Journal of Chemistry, 57, 1001-1004. http://dx.doi.org/10.1071/CH04084

[33] Costin, J.W., Lewis, S.W., Purcell, S.D., Waddell, L.R., Francis, P.S. and Barnett, N.W. (2007) Rapid Determination of Papaver somniferum Alkaloids Using Monolithic Column High-Performance Liquid Chromatography with Chemiluminescence Detection. Analytica Chimica Acta, 597, 19-23. http://dx.doi.org/10.1016/j.aca.2007.06.044

[34] Hindson, B.J., Francis, P.S., Purcell, S.D. and Barnett, N.W. (2007) Detemination of Opiate Alkaloids in Process Liquors Using Capillary Electrophoresis. Journal of Pharmaceutical and Biomedical Analysis, 43, 1164-1168. http://dx.doi.org/10.1016/j.jpba.2006.09.040

[35] Reid, R.G., Durham, D.G., Boyle, S.P., Low, N.S. and Wangboonskul, J. (2007) Differentiation of Opium and Poppy Straw Using Capillary Electrophoresis and Pattern Recognition Techniques. Analytica Chimica Acta, 605, 20-27. http://dx.doi.org/10.1016/j.aca.2007.10.023

[36] Barnett, N.W., Hindson, B.J. and Lewis, S.W. (2000) Determination of Morphine, Oripavine and Pseudomorphine Using Capillary Electrophoresis with Acidic Potassium Permanganate Chemiluminescence Detection. Analyst, 125, 91-95. http://dx.doi.org/10.1039/a906327g

[37] Odell, L.R., Skopec, J. and McCluskey, A. (2008) Isolation and Identification of Unique Marker Compounds from the Tasmanian Poppy Papaver somniferum N. Implications for the Identification of Illicit Heroin of Tasmanian Origin. Forensic Science International, 175, 202-208. http://dx.doi.org/10.1016/j.forsciint.2007.07.002

[38] El-Haj, B.M., Ali, H.S. and Hamoudi, N.M. (2011) Oripavine as a New Marker of Opiate Product Use. Forensic Toxicology, 29, 152-158. http://dx.doi.org/10.1007/s11419-011-0117-2

[39] Seki, I. (1970) Studies on the Morphine Alkaloids and Its Related Compounds. XVII. On-Step Preparations of Enol Ether and Pyrrolidinyl Dienamine of Normorphinone Derivatives. Chemical \& Pharmaceutical Bulletin, 18, 671-676. http://dx.doi.org/10.1248/cpb.18.671

[40] Coop, A. and Rice, K.C. (1998) A Novel Synthesis of Thebaine from Codeine. Heterocycles, 49, 43-47. http://dx.doi.org/10.3987/COM-98-S8

[41] Rapoport, H., Reist, H.N. and Lovell, C.H. (1956) Codeinone Dimethyl Ketal and Its Conversion to Thebaine. Journal of the American Chemical Society, 78, 5128. http://dx.doi.org/10.1021/ja01600a086

[42] Rapoport, H., Lovell, C.H., Reist, H.R. and Warren, M.E. (1967) The Synthesis of Thebaine and Northebaine from Codeinone Dimethyl Ketal. Journal of the American Chemical Society, 89, 1942-1947. http://dx.doi.org/10.1021/ja00984a032

[43] Bartels-Keith, J.R. and Hills, D.W. (1967) Syntheses Related to Northebaine. Part II. Derivatives of Nororipavine and 8,14-Dihydronororipavine. Journal of the Chemical Society C, 434-440.

[44] Singer, R.D. and Scammells, P.J. (2001) Alternative Methods for the $\mathrm{MnO}_{2}$ Oxidation of Codeine Methyl Ether to Thebaine Utilizing Ionic Liquid. Tetrahedron Letters, 42, 6831-6833.

[45] Barber, R.B. and Rapoport, H. (1975) Synthesis of Thebaine and Oripavine from Codeine and Morphine. Journal of Medicinal Chemistry, 18, 1074-1077. http://dx.doi.org/10.1021/jm00245a006

[46] Klein, P., Nelson, W.L., Yao, Y.H. and Simon, E.J. (1990) Electrophilic $\alpha$-methylene- $\gamma$-lactone and Isothiocyanate Opioid Ligands Related to Etorphine. Journal of Medicinal Chemistry, 33, 2286-2296. http://dx.doi.org/10.1021/jm00170a038

[47] Coop, A., Lewis, J.W. and Rice, K.C. (1996) Direct and Simple O-Demethylation of Thebaine to Oripavine. Journal of Organic Chemistry, 61, 6774.

[48] Coop, A., Janetka, J.W., Lewis, J.W. and Rice, K.C. (1998) L-Selectride as a General Reagent for the O-Demethylation and N-Decarbomethoxylation of Opium Alkaloids and Derivatives. Journal of Organic Chemistry, 63, 4392-4396. http://dx.doi.org/10.1021/jo9801972

[49] Sipos, A., Berenyi, S. and Antus, S. (2009) First Synthesis and Utilization of Oripavidine-A Concise and Efficient Route to Important Morphinans and Apomorphines. Helvetica Chimica Acta, 92, 1359-1365. http://dx.doi.org/10.1002/hlca.200800438

[50] McCamley, K., Ripper, J.A., Singer, R.D. and Scammells, P.J. (2003) Efficient N-Demethylation of Opiate Alkaloids Using a Modified Nonclassical Polonovski Reaction. Journal of Organic Chemistry, 68, 9847-9850. http://dx.doi.org/10.1021/jo035243z

[51] Dong, Z.M. and Scammells, P.J. (2007) New Methodology for the N-Demethylation of Opiate Alkaloids. Journal of Organic Chemistry, 72, 9881-9885. http://dx.doi.org/10.1021/jo071171q 
[52] Kok, G.B. and Scammells, P.J. (2010) N-Demethylation of N-methyl Alkaloids with Ferrocene. Bioorganic \& Medicinal Chemistry Letters, 20, 4499-4502. http://dx.doi.org/10.1016/j.bmcl.2010.06.031

[53] Kok, G.B., Pye, C.C., Singer, R.D. and Scammells, P.J. (2010) Two-Step Iron(0)-Mediated N-Demethylation of N-Methyl Alkaloids. Journal of Organic Chemistry, 75, 4806-4811. http://dx.doi.org/10.1021/jo1008492

[54] Kok, G.B. and Scammells, P.J. (2011) Further Investigations into the $N$-Demethylations of Oripavine Using Iron and Stainless Steel. Organic \& Biomolecular Chemistry, 9, 1008-1011. http://dx.doi.org/10.1039/c0ob01021a

[55] Kok, G.B. and Scammells, P.J. (2012) Improved Synthesis of 14-Hydroxy Opioid Pharmaceuticals and Intermediates. RSC Advances, 2, 11318-11325. http://dx.doi.org/10.1039/c2ra21693k

[56] Machara, A., Cox, D.P. and Hudlicky, T. (2011) Synthesis of Nalbuphine from Oripavine via N-Demethylation of N-Cyclobutylmethyl Oripavine. Heterocycles, 84, 615-623.

[57] Werner, L., Machara, A., Adams, D.R., Cox, D.P. and Hudlicky, T. (2011) Synthesis of Buprenorphine from Oripavine via N-Demethylation of Oripavine Quaternary Salts. Journal of Organic Chemistry, 76, 4628-4634. http://dx.doi.org/10.1021/jo200567n

[58] Machara, A., Werner, L., Endoma-Arias, M.A., Cox, D.P. and Hudlicky, T. (2012) Improved Synthesis of Buprenorphine from Thebaine and/or Oripavine via Palladium-Catalyzed N-Demethylation/Acylation and/or Concomitant O-Demethylation. Advanced Synthesis \& Catalysis, 354, 613-626. http://dx.doi.org/10.1002/adsc.201100807

[59] Mannino, A., Hoefgin, E.R., Hill, L.P. and Buehler, H.J. (2008) Use of Oripavine as a Starting Material for Buprenorphine. United States Patent, US 2008/0312441 A1.

[60] Wang, P.X., Jiang, T., Cantrell, G.L. and Berberich, D.W. (2012) Preparation of Oxymorphone from Oripavine. United States Patent, US 8,217,175 B2.

[61] Wang, P.X., Jiang, T., Cantrell, G.L. and Berberich, D.W. (2012) Opiate Reduction Utilizing Catalytic Hydrogen Transfer Reaction. United States Patent, US 8,309,727 B2.

[62] Huang, B.S. (2012) Process for Preparing Oxymorphone. United States Patent, US 8,134,002 B2.

[63] Huang, B.S. (2013) Process for Preparing Oxymorphone. United States Patent, US 8,357,802 B2. 
Scientific Research Publishing (SCIRP) is one of the largest Open Access journal publishers. It is currently publishing more than 200 open access, online, peer-reviewed journals covering a wide range of academic disciplines. SCIRP serves the worldwide academic communities and contributes to the progress and application of science with its publication.

Other selected journals from SCIRP are listed as below. Submit your manuscript to us via either submit@scirp.org or Online Submission Portal.
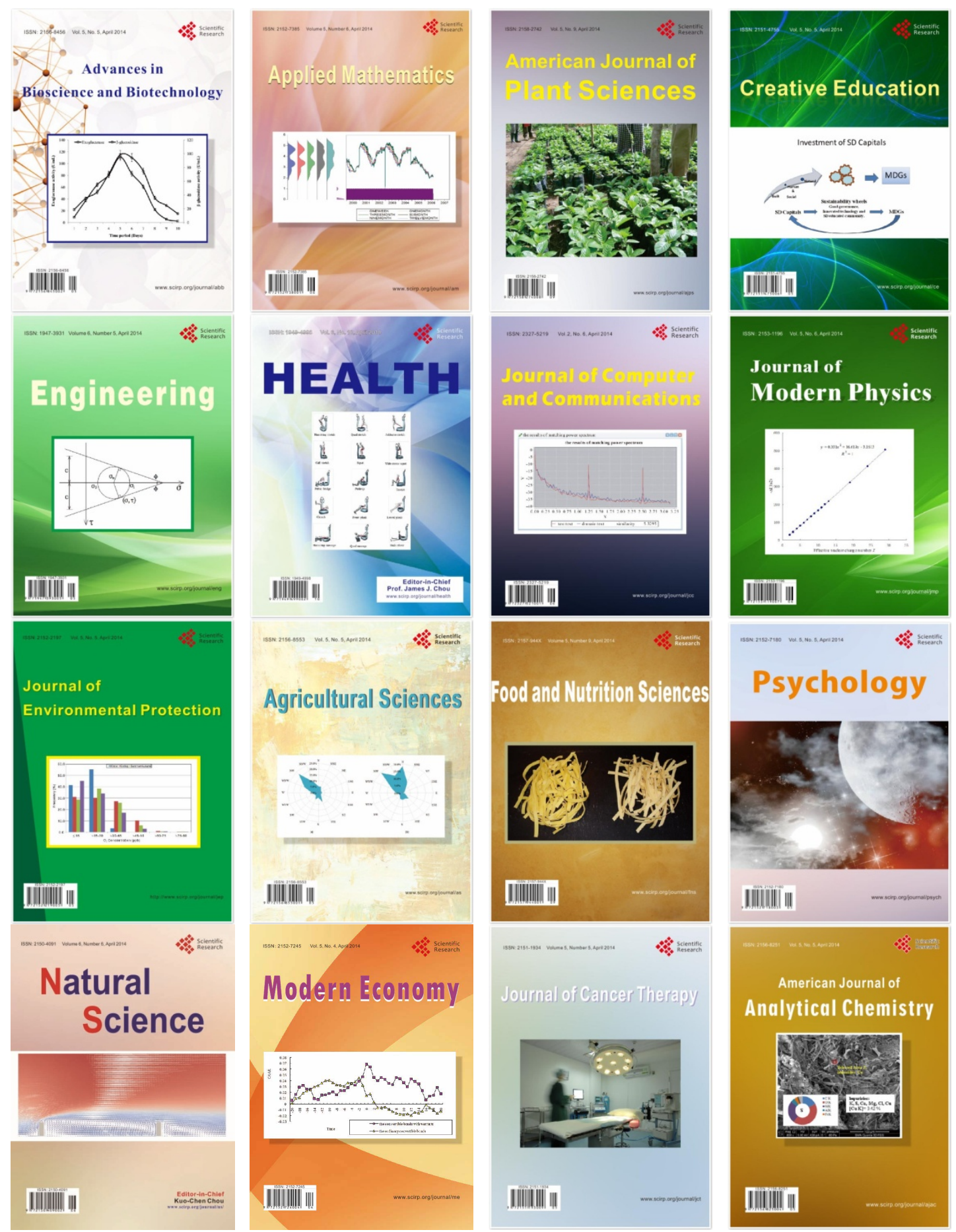